\title{
Effects of Prolonged Starvation on Cholesterol Content of Gonads in Clarias batrachus
}

\author{
Nayan Kumar Prasad \\ Department of Zoology, R.R.M. Campus, Janakpur, Tribhuvan University, Nepal \\ E-mail:nayankumar.prasad@gmail.com
}

Received: 2015.06.15, Accepted: 2015.08.13

\begin{abstract}
Starvation is experienced in most species of fish during certain periods of every year largely due to environmental conditions and it affects different organs in different ways. The present paper deals with the impact of starvation on cholesterol content of gonadal tissues of a fresh water catfish, Clarias batrachus. The level of cholesterol in the gonads has been found higher in female than in male under both the normal and starved conditions. Both the male and female gonads showed non-significant depletion up to 20 days of starvation but thereafter, it was sharp. After 40 days of starvation, the cholesterol depleted about $84 \%$ in male and $79 \%$ in female of their normal values.
\end{abstract}

Key words: Cholesterol, Clarias batrachus, gonads, starvation.

\section{Introduction}

Starvation affects the normal metabolism of the body and prolonged starvation may even cause death of the animal. The situation is pitiable in underdeveloped nations as well as developing countries. In fact, organism facing the starvation fights it at the cost of its own body-reserve till death. A decline in various body constituents of fish, following experimental starvation, have been reported by various authors. This paper deals with the results obtained for the fresh-water catfish, Clarias batrachus, following starvation up to 40 days.

The present study is aimed to know the facts and causes of starvation and their consequent impacts on animals. A number of similar studies have been carried out by many workers but most of the works have been confined to mammalian fauna. In Nepal, very little works have been done to study the starvation-induced effects in fishes. So, it is pertinent to see and reveal the effect of starvation on fish as there is a unique feature of fish to withstand prolonged starvation through physiological and biochemical changes (Mustafa, 1983). In fact starvation affects the physiological status and biochemical constituents of fish (Rajyasree and Naidu, 1989; Tripathi and Verma, 2003).

In the light of above fact, the present study has been designed to know the level of cholesterol content of gonadal tissue of Clarias batrachus during prolonged period of starvation of 40 days starting from 0 to 40 days by estimating cholesterol constituents at an interval of 10 days.

\section{Materials and methods}

For the present investigation, healthy live fish were collected from a local fish pond with the help of fishermen. The fish were brought to the laboratory in large earthen pots covered with mosquito net. They were 
identified according to Shrestha (1981) and were treated with $0.1 \% \mathrm{KMnO}_{4}$ solution for five minutes to get rid of any dermal infection. Healthy fish of an average length $(18.8 \mathrm{~cm})$ and weight $(34.4 \mathrm{~g})$ were transferred one by one with the help of small hand net to a large glass aquarium of about 110 litres capacity measuring about $75 \mathrm{~cm} \times 30 \mathrm{~cm} \times 45 \mathrm{~cm}$ in size. They were allowed to acclimatize under laboratory condition for 20 days. During this period, the fish were fed twice daily with commercial fish food to avoid their starvation. Twenty four hours before starting the experiment, the food was stopped to clear off the alimentary canal.

Biochemical estimations were made by taking the samples from each sex of acclimatized and well-fed fish and the values obtained were taken as normal value for $C$. batrachus. A control group was kept in tap water. The remaining fish were divided into four batches - A, B, C and D keeping 10 fishes each (5 males and 5 females). The fishes of batch A were kept without food at room temperature for 10 days, that of batch $\mathrm{B}$ for 20 days, $\mathrm{C}$ for 30 days and $\mathrm{D}$ for 40 days. The total cholesterol content of gonads was estimated by Sackett's method (1925) which is the modification of Bloor's method (1916).

\section{Results}

In present study, the gradual decline was observed in all the types of tissues in consideration. The gonads showed sharp depletion in cholesterol content due to starvation. The male showed more depletion of cholesterol content than that of female. However, both the male and female gonads showed non-significant depletion up to 20 days of starvation but thereafter it was sharp. After 40 days of starvation, the cholesterol depletion in gonads was about $84 \%$ in male and $79 \%$ in female (Table 1 , Fig. 1).

The analysis of variance and the bar notation of the recorded data showed that it decreased between each of the succeeding days intervals i.e. between 0 and 10 days, 0 and 20 days, 0 and 30 days, 0 and 40 days. In gonads, the cholesterol depletion between 30 days and 40 days of starvation was highly significant at $1 \%$ of $\mathrm{P}$.

\section{Discussion}

Cholesterol is a very important member of the sterol class of lipids. It is present in all cells both in the cell membrane and cytoplasm. All body fluids contain cholesterol except cerebrospinal fluid (Bell et al., 1976) in which the amount is negligible. The amount of cholesterol in any tissue is roughly proportional to their degree of activity (Chatterjee, 1980).

During starvation carbohydrates stored are utilized first to yield energy and when these fall below the critical value, lipids are mobilized. Cholesterol is utilized very economically at least in the brain (Bell et al., 1976). During the breakdown of alcohol, the lipid is converted into glucose (Chatterjee, 1980).

Depletion in the cholesterol content during starvation have been observed by various workers such as Borek (1958), Idler and Britners (1958), Shreni (1979), and Gatsko et al., (1982).

In the present investigation, sharp and significant depletion in the cholesterol content was observed following starvation. The catabolism of the cholesterol is under the influence of ACTH and thyroid hormone as the injection of ACTH and hyperthyroidism reduces the cholesterol content in the solid tissues and blood 
Narayan Kumar Prasad / Our Nature (2015), 13(1): 26-30.

Table 1. Cholesterol content in gonads ( $\mathrm{mg} / \mathrm{gm}$ wet weight) of Clarias batrachus during different period of starvation.

\begin{tabular}{lccccc}
\hline \multirow{2}{*}{ Name of organs } & \multicolumn{5}{c}{ Days of starvation } \\
\cline { 2 - 6 } & $\mathbf{0}$ & $\mathbf{1 0}$ & $\mathbf{2 0}$ & $\mathbf{3 0}$ & $\mathbf{4 0}$ \\
\hline \multirow{2}{*}{ Testis } & 13.05 & 11.17 & $8.95^{* *}$ & $6.27^{* *}$ & $2.06^{* *}$ \\
& \pm 0.23 & \pm 0.18 & \pm 0.21 & \pm 0.19 & \pm 0.11 \\
\hline \multirow{2}{*}{ Ovary } & 19.16 & $15.87^{* *}$ & $12.36^{* *}$ & $7.96^{* *}$ & $3.99^{* *}$ \\
& \pm 0.43 & \pm 0.54 & \pm 0.22 & \pm 0.28 & \pm 0.18 \\
\hline
\end{tabular}

Values are mean of 8 samples of both male and female $\pm \mathrm{SE}$, ** Significant.

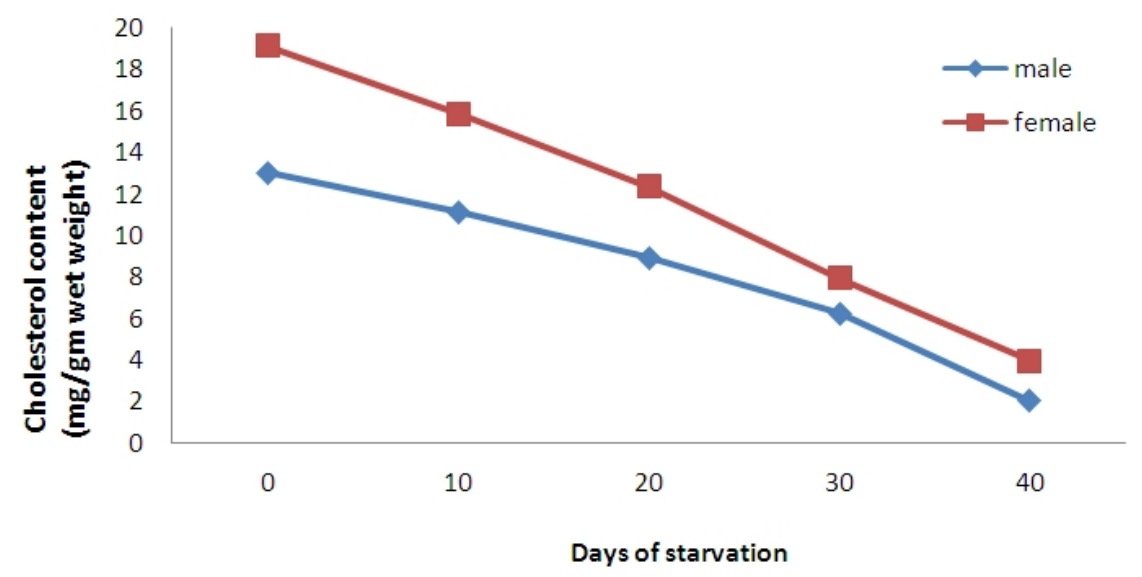

Figure 1. Effect of starvation on cholesterol content of gonads in Clarias batrachus.

(Chatterjee, 1980). Mueller et al. (1982) and Tang et al. (1983) observed variation in the secretion of thyroid and corticoids in starving animals. The present observations regarding the depletion of cholesterol level following starvation are in conformity with the findings of Idler and Britners (1958) and Shreni (1979). The sex difference of cholesterol content is in conformity with the observations of Shreni (1979).

The fall in the total lipid was observed by Greene (1919) and Olley and Duncan (1965) in Oncorhyncus tschawvtscha; and by Wilkins (1967) in Clupea harengus. Lovern (1934) reported selective drop of the highly unsaturated lipids when stores are being utilized. He further observed that depletion was more marked in males than females. Wilkins (1967) showed that a reduction in the proportion of lipid in Clupea harengus during starvation coincided with a reduction in certain protein fractions.

The fishes get maximum support from their environment which enables them to conduct their activities without recourse to their body constituents and so their basal energy consumption is very low. For this reason, fish are able to withstand astonishingly long periods of starvation such as, Amia calva survived for 20 months without food (Smallwood, 1916), Clupea harengus survived for 129 days (Wilkins, 1967), and above all Anguilla anguilla managed to live without food for 15 days (Boetius and Boetius, 1967). 
Effect of prolonged as well as short term starvation has been extensively studied, mostly on temperate fish. In the present investigation, the cholesterol store of the gonads did not show significant drop up to 20 days of starvation. When the cholesterol stores of liver and muscle dropped below $50 \%$ of the normal, the cholesterol stores of gonad started to drop sharply. After 40 days of starvation gonad showed cholesterol depletion almost equivalent to that of muscles.

The value of cholesterol and glucose was found higher in females than males under both normal and starved condition. This finding of sex difference is in conformity with Singhal et al. (1981).

\section{Conclusion}

From this study, it is quite evident that when Clarias was subjected to starvation stress, the animal successfully overcame the stressful period and survived all throughout the starvation.

The level of cholesterol in the gonads have been found higher in females than that of males under both the normal and starved conditions. The main cause for the depletion in cholesterol level was the effect of starvation stress as indicated by the control group. After 40 days of starvation, testes showed more depletion in cholesterol content as compared to the ovaries.

\section{Acknowledgements}

The author renders his heartfelt gratitude to Dr. R.P. Sinha and to Dr. A.K. Verma, Professors, Department of Zoology, C.M. Science College, LNMU, Darbhanga, for their generous and constant guidance as well as for providing lab facilities during the whole research work.

\section{References}

Bell, G.H., D.E. Smith and C.R. Peterson 1976. Text Book of Physiology and biochemistry $\left(9^{\text {th }}\right.$ ed.). Livingstone, Edinberg, England.

Bloor, W.R. 1916. The determination of cholesterol in blood. J. Biol. Chem. 24: 227-231.

Boetius, L. and J. Boetius 1967. Studies on the European eel Anguilla anguilla (L). Maddel. Dan. Fisk. Havunder. 4: 339-405.

Borek, Z. 1958. The contents of lipids and other components in the Cruciaris (Carassius carassius L.) body during hibernation and experimental starvation. Pol. Arch. Hydrobiol. 5(1): 65-91.

Chatterjee, C.C. 1980. Human Physiology. Vol. 1, M.A.A., Calcutta.

Gatsko, G.G., L.M. Mazhul and E.A. Pozdnyakova 1982. Lipid peroxidation in tissues of normal and hungry rats of different ages. Bull. Exp. Biol. Mad. 93(4): 416-418.

http://dx.doi.org/10.1007/BF00830537

Greene, C.W. 1919. Biochemical changes in the tissues of king salmon during the fast of spawning migration. J. Biol. Chem. 39: 435-456.

Idler, D.R. and I. Britners 1958. Biochemical studies on sockeye salmon during spawning migration. II. Cholesterol, fat, protein, and water in the flesh of standard fish. Can. J. Biochem. Physiol. 36: 793798. http://dx.doi.org/10.1139/o58-084

Lovern, J.A. 1934. Fat metabolism in fish. Mobilization of fat in salmon. Biochem. J. 28: 1955-1960. http://dx.doi.org/10.1042/bj0281961

Mueller, M.J., U. Paschan and H.J. Seitz 1982. Role of thyroid hormones in the metabolic adaptation to starvation in the miniature pig. Acta. Endocrinol. Suppl. 99(246): 76-77.

Mustafa, S. 1983. Changes in biochemical composition in starving Catfish Heteropneustes fossilis. Japanese Journal of Ichthyology 29(4): 416-420.

Olley, J. and W.R.H. Duncan 1965. Lipids and protein determination fish. J. sci. Agric. 16(2): 99-104.

Rajyasree, M. and K.R.P. Naidu 1989. Starvation induced changes in biochemical aspects of hepatic tissue of fish, Labeo rohita. Indian J. Fish. 36: 339-341.

Sackett, G.E. 1925. Modification of Bloor's method for the determination of cholesterol in whole blood or blood serum. J. Biol. Chem. 64: 203-205.

Shreni, D.K. 1979. Influence of starvation on the brain and liver cholesterol levels of catfish, Heteropneustus fossilis (Bloch). Proc. Animal Sci. 
Narayan Kumar Prasad / Our Nature (2015), 13(1): 26-30.

88(3):205-208.

http://dx.doi.org/10.1007/BF03179095

Shrestha, J. 1981. Fishes of Nepal ( $1^{\text {st }}$ ed. $)$. Curriculum Development Centre, T.U., Kathmandu, Nepal.

Singhal, P.C., R.K. Gupta and L.D. Joshi 1981.Effect of sex on blood sugar levels on experimental animals. I. J. Exp. Biol. 19: 1201-1202.

Smallwood, W.M. 1916. Twenty month of starvation in Amia calva. Biol. Bull. Mar. Biol. Lab. Woods hols 31: 453-464.

Tang, F., C.P. Lee and A.C.L. Hsieh 1983.
Synergistic effects of cold and starvation on the plasma levels of corticosterons in male rat. Acta. Endocrinol. 103: 256-277.

Tripathi, G. and P. Verma 2003. Starvation-induced impairment of metabolism in a freshwater Catfish. Z. Naturforsch. 58c: 446-451.

http://dx.doi.org/10.1515/znc-2003-5-626

Wilkins, N.P. 1967. Starvation of the herring, Clupea harengus L: survival and some gross biochemical changes. Comp. Biochem. Physiol. 23: 503-518. http://dx.doi.org/10.1016/0010-406X(67)90402-1 